\title{
Ministerial dress for worship in Southern Africa Presbyterianism
}

\author{
G A Duncan ${ }^{1}$ \\ Department of Church History and Church Polity \\ University of Pretoria
}

\begin{abstract}
In view of Scripture, theology of worship, symbolism, history, tradition and current practice it is difficult, if not impossible, to come to any definite conclusions about ministerial dress in Presbyterian worship. The dissonance between the theological approaches of those who wear robes and those who do not, both of which positions are justifiable in the author's opinion appears to be the main problem. Another serious issue lies in the fact that this issue generates more emotion than insight when it is raised. Furthermore, robes are non-essentials with regard to how we express our faith. Thus an appropriate stance would be the exercise of "liberty of opinion ..." since it would be difficult to reconcile the diversity that already exists. Resolving the matter by legislating it for all time, is contrary to our Reforming tradition. A more sensitive, open approach will lead to decency and order, peace and mutual acceptance as far as this non-essential aspect of the life and witness of the Church is concerned.
\end{abstract}

\author{
Church Clothes \\ The chameleon charms with wizardry \\ to escape his humble lizardry, \\ blending in with vain show blizzardry, \\ Chameleon is confused. \\ The peacock moves with pageantry, \\ unfolding feathered tapestry, \\ to hide would be disastery, \\ Peacock is convinced.
}

\footnotetext{
${ }^{1}$ The author wishes to express his thanks to his long term mentor, Rev J C Stewart retired minister, Aberdeen, UK, for his assistance in tracing material which is not easily available, and Stephan Greyling, post-graduate student at the University of Pretoria for translating Roets and Dreyer's article from Afrikaans.
} 
And which will dress our history, bold plumes or image shiftery? Word, sacrament and mystery, or blending in confused?

Richard C Lambert

\section{INTRODUCTION}

"Any uniformity in clerical dress among Presbyterian ministers has never been realised, particularly in America" (Macleod 1990:126). This is also true in southern Africa since the union which brought the Uniting Presbyterian Church in Southern Africa (UPCSA) into being in 1999. Prior to that the former Reformed Presbyterian Church in Southern Africa (RPCSA) had a distinctive approach to ministerial dress which was inherited directly from Scotland and was very formal. ${ }^{2}$ The Presbyterian Church in Southern Africa (PCSA) had two traditions; one was identical to that of the RPCSA; the other is far less formal and depends predominantly on the ethos of individual congregations. However, within these broad traditions there are variations in dress.

The union has highlighted these differences in practice and there would appear to be a desire on the part of some to achieve a degree of uniformity. Whether that is a good thing or not is also a contentious issue. A recent debate on the design of the UPCSA Moderator of General Assembly's stole demonstrated how so much time and energy can be devoted to a matter that is simply not of the "substance of the faith" and therefore could be considered a matter where "liberty of opinion" is exercised (UPCSA 2003:69).

There is no evidence in any of the Reformed confessions of faith or in their books of order (McMillan 1949:25) of directions given regarding how ministers should dress for public worship. This clearly was not a matter of great import. Yet, this is an emotive matter in some quarters. It is contextual and, despite the attitude taken with regard to dress, what we wear is an integral part of our worship because we do not worship naked. Our worship is based in a theological understanding of what worship is.

\section{THEOLOGY OF WORSHIP}

The history of salvation is the record of God who in self giving love takes the initiative in reaching out to human beings in order to bring us into a closer covenant relationship, seeking our response of faith. A history of human failure resulted in the Incarnation which facilitates this faith response which is

\footnotetext{
${ }^{2}$ In general, the other two black Presbyterian churches, the Presbyterian Church of Africa and the Evangelical Presbyterian Church in Southern Africa have followed this tradition.
} 
motivated in and through the Holy Spirit by means of the response of Christ to the glory of God. This is the basis of Christian worship. That worship, God's communication and human response, is materialistic that is incarnational and sacramental. It involves the totality of our being, all our senses: sight architecture, vestments, colour; taste and touch - water, bread and wine, oil and texture; hearing - Word, words and music; smell - incense, flowers. Worship is the communal celebration of the Church; it is about communication. This communication may be described as liturgical, theological, political and personal. It extends even to our dress for worship: "Even our clothing is an important part of worship. It testifies to our understanding of the occasion and our role in it as well as facilitating or constraining meaningful movement" (White 1980:103).

\section{TRADITIONS}

Two traditions relating to dress emerge from scripture.

\subsection{The priestly tradition}

This tradition follows the Hebrew Bible tradition of the Temple priests who received exacting and clear instructions regarding dress. The instructions are complex which indicates that they were important enough for God to enable this unsophisticated people en route to the promised land to make them (Groeneveld 2005:1). Exodus 28 gives some indication of the purpose of vestments. They are to confer dignity and grandeur to worship ( $v 2)$. A list of garments is given which are multi-coloured and bejewelled ( $v$ 4-42). The High Priest's vestments were of "regal magnificence" (North 1957:211). And they are to be worn "whenever they enter the Tent of Meeting or approach the altar to minister in the Holy Place" ( $v 43$ ), that is to offer sacrifice. Among their other functions, priests were "to ascertain the will of God" (1 Sm 23:6-12), "to deliver toroth (instruction, law $\mathrm{Hg}$ 2:11-13). This view was taken up by Clement of Rome, around the end of the first century CE who erred in his assumption that the New Testament ministry of the presbyter bishop followed the practice of the OT priesthood (First Letter, 42-44 in Richardson 1953:39). In fact, Temple worship made little impression on Christian worship; it followed the synagogue tradition.

\subsection{The synagogue tradition}

This tradition has its roots in the post-Exilic synagogue worship which grew out of the Jewish Diaspora or Dispersion, not the Temple. "Corporate worship was offered in the house of any believer who had a room conveniently large" 
(McEwen 1957:289). There is no mention about how those presiding at worship should dress and it would appear that they simply wore normal everyday dress. The New Testament gives us no guidance about dress. Perhaps this is because "any member of the congregation might be invited to lead the prayers and expound the scriptures" (Carpenter 1957:146). Symbolic reference, using a military metaphor, is made to the Christian's armour (Eph 6:10-17) the various items of which symbolise truth, righteousness, peace, faith, salvation and the Spirit. This applies to the entire Christian fellowship which is contrary to the Hebrew Bible tradition where it is the priesthood which is "clothed with salvation" (Ps 132:16). In Paul, we find the concept of induere Christum "putting on Christ" (Rm 13:14; GI 3:27) which infers ideas of justification and sanctification and, further "Induere Christum stands in relation to the idea of putting on a garment. Clothes when put on, almost become part of the person; we live and move in them. So, when we are putting on Christ, Christ becomes the element in which we move and live" (Behrendt 2001:439). It "gives us a new character, makes us complete" (Behrendt 2001:440). It is a matter of identity. This is also related to the armour metaphor. The Romans text refers to "put on the armour of light" (Rm 13:12) which is expressed in Luke 24:49 which refers to being "clothed with power from on high".

There is a degree of continuity between the Jewish and Christian ministry based in the synagogue as the result of the work of Christ which transformed the nature of the ancient ministry. The entire priestly and sacrificial system was superseded by its fulfilment of Christ's priesthood and sacrifice: "the Mosaic Law ceased as a ceremonial code to be binding on Christians, and therefore needed no professional scribes to expound and interpret it" (Carpenter 1957:146). This resembles some aspects of the modern Liturgical Movement where worship is the work (leitourgia) of the people (laos) (Wainwright 1978:38). The second century Teaching of the Twelve Apostles, Commonly Called the Didache, the first church order available to us, contained no instructions on dress (Richardson 1953:161).

\section{HISTORY OF VESTMENTS}

Two views emerge here.

\subsection{The priestly view}

One is that the minister is different; s/he is special as the result of ordination that is a separated one, and should therefore dress differently to indicate the different role in worship. Vestments have been described as a "separator ... 
not only from the world, but from less devout and observant members and from the uninitiated" (Cannon 1992:142). But, more than that:

... the garment makes the wearer what it represents ... shows particular dignity and makes known a particular state or station in society. It means not only something extrinsic, but rather a quality which affects the wearer intrinsically, and this quality does not stem from the person, but is bestowed upon one from without.

(Behrendt 2001:449)

Robes are "often used by institutions to depersonalise the wearer in order to emphasise the primacy of the institutional role over the personality" (Bradshaw 2002:464; cf Oden 1983:131) and "sinks the individual and the man of the passing age" (Sprott 1882:243).

The use of black in the Reformed/Presbyterian tradition (McMillan 1949 $25,26 ; 1949 a: 33)$ is indicative of a masking of the personality in order that God's Word might be conveyed beyond the hindrance of individual personality. The use of black is defended: "black connotes seriousness, an absorption with higher concerns" (Marty 2001:31). Practically, it is more appropriate for the European climate in which it was adopted and has been maintained for centuries.

Interestingly enough, white was the preferred colour in the Early Church for any form of vesture and finds its authority in scripture. (Rev 3:18; $7: 9 ; 15: 6 ; 19: 14)$. Neophytes of the fourth and fifth centuries CE wore a white garment symbolic of innocence according to Ambrose (De Myst 7.34, in Behrendt 2001:450; cf Yarnold 1978:104).

\subsection{The synagogue view}

The other view is that, in essence, the minister/president at worship is no different from any other member of the laos of God, that there is no need for difference to be expressed through dress. Hence, all should dress in similar manner that is in secular dress. Pullain ${ }^{3}$ (in Maxwell 1965:210) confirms that the New Testament does not prescribe special dress for its ministers, and suggests that "a shepherd is not known to his sheep by his garb but by his call to them, and he thinks it sufficient that a Minister should be dressed modestly and soberly, with an absence of all pomp and circumstance". Originally, this is what happened as far back as we can trace in the Early Church. When it was co-opted by Emperor Constantine as a department of state, "The church now

\footnotetext{
${ }^{3}$ Ad lectorum candidum (Lit sac., $P, Q$ ).
} 
borrowed much from the civil magistracy ... [inter alia] the clothes" (Wainwright 1978:35). It became the norm for priests to wear the secular garb of state officials for example the stole was a badge of office of a civil servant. Further, "the robe of the Roman catholic church was worn to establish an hierarchical division between the clerus and the laypeople. The clerus had absolute power, it was only them [sic] who could interpret Scripture. There was a giant distance between clerus and people" (Roets \& Dreyer 2001:1349). The English historian, Bede, supported this view in his Martyrdom of St Alban in 301 CE:

From all these things we learn that we ought not to enter the Holy of Holies clad in our everyday garments and in whatever clothes we will, defiled as they are by the usage of common life: but with pure conscience and in pure garments we ought to hold the sacraments of the Lord.

(in PCSA 1988:49)

Following the reformation, an Act of the General Assembly of the Church of Scotland forbad ministers from wearing gaudy clothes or plaids ${ }^{4}$ when conducting worship. This would indicate that ecclesiastical dress was not worn at this time. One tradition re-emerged in Scotland which was evident in the eighteenth century, where "colleagues in the neighbouring parishes wear ordinary clothes and a hat" (Ross 1972:19) as can be seen in H G Graham's (1909:308 in Burnet 1960:29) comment that ministers wear "blue coats and bob-wigs". Maxwell (1955:81) enlightens us further by declaring that from 1638 "for the first time many [ministers] appeared in Glasgow in ordinary clothes and arms [weapons!]", perhaps not so far removed from some instances in the southern African situation!

\subsection{The Reformation and beyond}

At the time of the Reformation, there was no agreed practice with regard to clerical dress. Many Reformers discarded most of the traditional vestments and wore normal outdoor dress in church (Sprott 1882:243). However, these were retained in Luther's Formulae Missae and Diebold Schwarz' mass (Maxwell 1936:77, 88). In 1525, Zwingli, in his German communion service decreed that only the cassock and gown be worn (Senn 1997:362). These were normally black or other dark colours. The oldest surviving Protestant community, the Unitas Fratrum, wore no special vestments. During the

\footnotetext{
${ }^{4}$ An extension of the kilt worn over the left shoulder.
} 
Vestiarian controversy in the Church of England during the reign of Edward VI (1547-1553) Bishop John Hooper based his "objection to the use of vestments on the sufficiency of the Word of God as the directory for ceremonial" (Davies 1963:16). He wore them for this occasion on condition that he could dispense with them afterwards. In this Hooper was supported by the reformers Bucer, Martyr, Calvin and Knox, while he was opposed by à Lasco and Bullinger (McNeill 1954:309). Maxwell (1955:51) defines outdoor dress as "cassock, gown, hood, scarf, bands or other neckwear, cap and gloves." However, this dress became problematic when it was associated with the Episcopalian periods forced on the Church of Scotland during the seventeenth century and was abandoned until around the close of the eighteenth century (Maxwell 1955:130-1). An example is given when "the late Dr Wightman, minister of Kirkmahoe, a parish close to the town of Dumfries, began to use a gown in the pulpit, there was quite a rebellion in the community, and many left the church, headed by the precentor (leader of praise), who refused to sit and sing under a man clothed with such a Babylonish garment" (Sprott 1882:245). The antipathy to "vestments and other ceremonies likewise lacked God's sanction and therefore were mere human inventions and relics of popery" (White 1989:125). They have a further role as ministerial dress "maintains traditions, defines the community, and serves as a bridge for future generations" (Salamone 2004:93) as well as conveying authority (Sprott 1882:243) and spiritual values. So it is clear that there was no absolute Reformed view. There never was a unitary view about ministerial dress. This tended to be the prerogative of the Roman Catholic, Anglican and Orthodox traditions.

"Only by association with the ministerial office has it [vestments] taken on symbolic meaning. Indeed, clerical dress at many stages of history, chiefly on account of the conservatism of the church, was merely the common style of a previous generation" (Macleod 1990:127). Lindberg (1996:328) raises this issue with regard to the Vestiarian Controversy which focused on the theological status of adiophora - matters of indifference or inessentials. Historically, adiophora become normative over time. What appeared to be an apparently insignificant matter implied the continuation of a priestly order symbolized by separate clerical dress within the Reformed churches.

Steinmetz (1971:148) offers a perceptive comment that if vestments "be kept in the churches as things indifferent, at length they will be maintained as things necessary" though "both in the Church at large and in particular parishes, it takes a very short time indeed to make an entirely new tradition" (Sprott 1882:245). And so it has become for many. However, an important warning was sounded over a hundred years ago concerning this issue: 
... all who desire to manifest an intelligent appreciation of what is distinctive in Presbyterian ritual, would do well to guard against attaching undue importance or adhering too tenaciously to details of a past or present usage, as if these constituted the essentials from which there must never be the smallest deviation, of which there may never be the slightest modification or adaptation to altered requirements and circumstances.

(M'Crie 1898:355)

From another perspective, the Reformed tradition may be summarized as:

... it will not deliberately scorn tradition or despise a widely prevailing custom. It will retain and borrow what may be desirable, adapting it to its practical and liturgical needs. It will not be fettered by the customs of the Universal Church and the traditions of the ages, but it will seek to reverence and understand them, avoiding the confusion which makes them vain ....

(Hamilton 1946:27)

This tradition has predominated in the Reforming tradition and has become the norm in many Reformed Churches. It has even been exported beyond its European origins to African and Asian countries where black is inappropriate in terms of colour and materials used.

However, more positively: "the vesture of the officiating ministers and their assistants is one of these factors, secondary in themselves, which contribute to the total effect of the celebration, and is therefore deserving of serious attention" (Grisbrooke 1978:488).

\section{TRADITIONAL REFORMED MINISTERIAL DRESS}

Modern ministerial wear has developed over a number of centuries and the distinction between ordinary outdoor dress and what was required to be worn for ministerial duties has been obscured in the course of time.

\subsection{Cassock}

As with other vestments, the cassock was not originally a liturgical vestment (McMillan 1949a:32). From 1604, it was decreed that the cassock would be the main outdoor garment of all clergy and it continues today to worn mainly as an indoor vestment. It resembles the alb although it was originally designed to be worn under it. It is normally single or double breasted. This is an ankle length garment which is gathered at the waist by either a: 


\subsection{Girdle (tassled cord), cincture (band or sash) or belt}

These draw the waist of the cassock in to allow for greater freedom of movement (James 1936:172).

\subsection{Preaching gown}

The gown has been the basic garment which has been the foundation of secular and clerical wear for more than 900 years, that is it predates the Reformation. It may have been lined with fur to suit the European climate (Ross 1972:4) and remnants of this may be seen in the academic hoods of Edinburgh and St Andrews Universities which are fur-lined. Originally the hood or cowl was attached to the gown. It was adopted for academic wear in the fourteenth century (Wippell 1989:37). This was the outdoor wear of the Renaissance and Reformation periods worn by academics and lawyers. In 1609 , James $\mathrm{VI}$, with the authority of Parliament, decreed that black gowns should be worn in the pulpit (Ross 1972:48). His concern was to "control all ecclesiastical matters ... even to such details as the regulation of clerical dress" (Burnet 1960:67). Following the Restoration (1660) robes came to be associated with episcopacy and was consequently rejected. These black robes were the cassock and "Genevan" gown as we know it today. Blue became a favoured colour for gowns where worn, and this may be the origin of the colour blue as the true Presbyterian colour. ${ }^{5}$ From the seventeenth century this form of dress was extended to all clergy. Both clerical and academic gowns are permissible. Various designs are worn.

\subsection{Shirt, collar and bands}

The collar and bands were worn over a white collarless shirt which was an undergarment with long sleeves and gathered wrists. The original collar was derived from the amice, a neckcloth in the vestments of the Mass; it became in Tudor times a matching long white neckcloth wrapped around the neck and the bands have their origin in the ends of the scarf which hung done at each end (Mayo 1984:134). They were in use in England and Scotland from1566. By the eighteenth century the collar and bands were stylised in the form we know them today (White 1980:108). The clerical collar ${ }^{6}$ was an early nineteenth century development and the depth of collar was intended to draw a distinction between dissenting ministers and the ministry of the established church, the deeper the collar the greater the level of dissent! The tradition in the UPCSA and its predecessors is that the clerical collar is worn from the time of licensing while the bands are only worn following ordination (UPCSA

\footnotetext{
${ }^{5}$ Blue cassocks are favoured in Scotland by many young ministers today.

${ }^{6}$ Often referred to in derogatory terms as the "dog collar".
} 
1984:201.01E). This is strange given that they historically form part of the same garment.

\subsection{Academic hood}

Academic hoods, which are optional and are not properly speaking liturgical garments, are commonly worn to signify a strong commitment to an academically trained Reformed ministry: "The Reformation of the sixteenth century was chiefly led by men of high academic attainments, propagated by the select band of clergy whose main work was preaching" (Tripp 1978:250). This was due to "the prevailing ignorance and superstition inherited from the Roman Church [where the Reformers] ... saw the necessity of a welleducated ministry and an intelligent laity" (Burnet 1960:44). The Anglican 1549 Book of Common Prayer recommends hoods as seemly for preachers and the 1604 canons (XXV and LVII) order the wearing of academic hoods for all graduate ministers and this has been one norm of vesture in the Reformed churches (Davies 1986:534). Although the hood is an academic badge (we must remember that the stole was originally a civil badge) it also has its roots in the clerical cowl and the "Tippet" "an old university decoration, which in its origin was part of the hood" (McMillan 1931:364). The design and colour is prescribed by the awarding university. Hoods have an aesthetic value in that they add colour to otherwise drab black garments (McMillan 1949a:39). Objections have been raised to the wearing of hoods (Macleod 1990:127) on the grounds that they are elitist. ${ }^{7}$ However, that might be said of every article of clerical garb. Academic hoods are part of the Scottish tradition on which both constituents of the UPCSA are founded. It may be interesting to note that they are less in evidence today, except on special occasions. The "General Directions for Presbytery Services" (PCSA 1984:201.01E) acknowledges the use of hoods in the direction that they "are not worn at a service of Holy Communion or at a burial service". No rationale, however, is provided for this instruction which only applies to Presbytery services. ${ }^{8}$ Yet, while it might seem

\footnotetext{
7 "The original reason why Luther wore his doctoral robe in 1524 was to show that he had the necessary academic proficiency at his disposal to interpret and proclaim the Word. He definitely did not want to brag with his robe. On the contrary, he knew that he was a preacher of the Word, solely by grace, and that was about God's glory, and not his own" (Roets \& Dreyer 2001:1350).

${ }^{8}$ This is interesting in a Presbyterian church whose worship is guided by a Book of Common Order, which only provides guidance and a standard for worship, in distinction to a Book of Common Prayer (e g Anglican) where detailed rubrics (instructions) are given which are to be followed slavishly (cf Burnet 1960:12 referring to Knox's "Liturgy": "The Book of Common Order is not a liturgy, strictly speaking. Rather it is a guide to public worship for ministers ... Its use was not fixed and obligatory, although the officiating minister was clearly not meant to depart from, or to vary too much, the actual form of words according to his own predilections"). It is also interesting to note that for as many people as are approached for an explanation of this direction concerning occasions where hoods are not to be worn, there are an equal number of interpretations!
} 
appropriate for hoods not to be worn at funerals there have been instances where it has been considered very appropriate. For example, when a former General Secretary of the RPCSA, Rev S B Ngcobo, passed away in June 1994, all ministers wore academic hoods at the funeral as a tribute and a mark of respect. ${ }^{9}$ It is also common in the black community for academic hoods to be worn by all graduates at the funeral of a graduate.

\subsection{Preaching scarf}

The scarf is distinct from the hood and should not be confused with it. Their origins and history are quite different. Therefore, Macleod (1990:130) may be confusing the scarf and stole when he claims that early prints show stoles being worn by John Knox and Andrew Melville, and that the "stole has come into more general use from the mid-nineteenth century to the present day." He also alludes to Moderators of General Assembly in Scotland wearing stoles from 1890 as is evidenced in extant portraits of Moderators, but this almost certainly refers to preaching scarves. The scarf, in fact, appears to be a remnant of the tippet which was originally part of the academic hood (Hamilton 1946:33). It constitutes yet another mark of ordination. Plain black preaching scarves have virtually disappeared from use nowadays.

\section{$5.7 \quad$ Stole}

A stole is a strip of coloured cloth worn around the neck. It originated in the imperial Roman and Byzantine courts as a badge of office in the civil service and was called the orarium until the eleventh century CE. Stoles were worn by leaders of worship in the early church (Hamilton 1946:28): "It may go back to near the time of the Apostles, or even to that of the Apostles themselves. For ... a Reformed Church with its insistence on apostolic beliefs as opposed to medieval accretions, the stole would seem to possess a fitting symbolism." The stole is the badge of an ordained minister and is normally worn at sacramental services. However, Fortescue (in Hamilton 1946:32) has claimed that "There is no authority for the stole except recognized custom."

Nowadays stoles are made of various materials and properly worn should accord with the appropriate liturgical seasons, that is

Purple, blue or brown

White, gold or yellow
Advent, Lent

Easter (six weeks), Christmas (12 days until Epiphany), Trinity Sunday, weddings, funerals

\footnotetext{
${ }^{9}$ Author's personal recollection.
} 
Red

Green

No colour
Pentecost, Holy Week, Ordinations, commemorations.

Ordinary Time (the rest of the year) (Senn 1997:607).

Good Friday, Holy Saturday.

At times single or multi-coloured stoles are worn throughout the year.

Hamilton suggests that if only one coloured is used, white is preferred in a Reformed church as symbolising primitive (pure) Christianity (Hamilton 1946:35). Stoles can be either two-part with both parts hanging at the front of robes, or three-part with a third, slightly broader part hanging at the back (derived from the epitrachelion of the Eastern Church). The three-part stole is less appropriate when worn with traditional robes. It would be an interesting exercise to provide guidance for colours to be used on commemorative days which have now become public holidays for example June $16^{\text {th }}$, Youth Day.

The Moderator of the General Assembly of the UPCSA wears a "ceremonial" stole as opposed to a "sacramental" stole, described above. This is one of the badges of office (inherited from the RPCSA tradition) along with the ring (inherited from the PCSA tradition) and the moderatorial gown (inherited from both traditions).

\subsection{Cap}

Ministers wore caps for worship for some time following the Reformation and these were replaced by three cornered hats by the eighteenth century. They gradually disappeared from use as male fashion changed. A righteous remnant of Church of Scotland Queen's chaplains still wear the tricorn hat on ceremonial occasions.

\subsection{Modern options}

There are several single vestment options which vary only slightly from one another. These include the $A l b$ (a long tunic of pre Christian origin), Chalb (a combined chasuble/alb; also called a tunika) and Cassock Alb (a combined cassock/alb and resembles the chalb but is less full skirted). These are simple garments in design and which can be worn with a stole. Some ministers of the UPCSA have been wearing such garments for some time and this was sanctioned by the General Assembly in 1988 (PCSA 1988a:32). Their advantage is that they are light in weight and colour and therefore more appropriate to the southern African climate. A disadvantage may be that they 
are associated with recent developments in vesture of the Roman Catholic and Anglican traditions. Consideration was given prior to union to adopting a garment of this type for the Moderator of General Assembly of the UPCSA, but it was decided not to proceed with such an innovation at that time.

\section{SYMBOLISM}

The issue of the symbolism attached to items of dress is vexed because for there are many interpretations of symbolism. For example, the text Mt 11:2930, "Take my yoke upon you, and learn from me, for I am gentle and humblehearted; and you will find rest for your souls. For my yoke is easy to wear, my load is light", has been used to symbolize the use of both the stole and the clerical collar. Further, the girdle worn around the waist of the cassock might be taken to be symbolic of the leather belt worn by John the Baptist (Mk 1:6) and/or of the freedom we have in Christ.

As time progressed into the Medieval period, the origins of vestments was forgotten and so a rationale was devised in terms of a "more or less complicated system of symbolism, some of it simple and reasonably obvious, some of it - and more and more of it as time went on - abstruse and artificial, and most of it varying, of course, from one part of Christendom to the other" (Grisbrooke 1978:489). Three forms of symbolism emerged: first, to find biblical warrant for vestments inter alia; second, to find justification in details of the passion narrative; and third, to express symbolism through moralism "a symbolism of virtues and graces" (Grisbrooke 1978:490).

Much more could be said here but what is important is that within the Reforming tradition, history plays a greater role than symbolism although the significance of symbolism should not be minimized especially in terms of its relationship to our common identity: "Dress has always been a way in which people of a particular time and place express their identity. Individuals fulfilling liturgical functions have usually been distinguished by special vestments and churches should reflect carefully on the meaning conveyed by such symbols" (Thurian \& Wainwright 1983:239). Recent research in South Africa in two of the churches from the Dutch Reformed tradition has demonstrated that "Liturgical symbols awaken a 'belonging to' in the believer" (Roets \& Dreyer 2001:1347). That is, they testify to our identity. This is particularly true of the preaching gown where the gown is a "symbol that this is God's Word, and not his or her word .... The minister is subservient to the Word that he or she brings, and the robe is a symbol of this .... It symbolizes something of the presence of God" (Roets \& Dreyer 1348-1349). Of course, this is equally true of those whose "vestments" are contemporary everyday wear. 
Since vestments have undergone periods of rejection and revival, and the recognition that some features have become anachronistic, there needs to be regular reappraisal of the symbolism of vesture to ascertain its relevance and effectiveness and as an expression of historical continuity (Davies 1986:535). Criteria which are worthy of consideration here include the aesthetic, theological and historical, and functional.

\section{WHAT IS THE REAL ISSUE HERE?}

The question must be is it important to define closely what ministers should wear when conducting worship? Is it a matter worth causing possible division in the church (cf PCSA 1988a:32), because we also need to be aware that congregations and congregants tend to have strong views about how their ministers should dress. Is it a matter which should be forced on ministers who also have strong views on the matter which might conflict with their congregation's views? Is there a basic minimum requirement that should be enforced as in requirements for licensing and ordination with regard to collar and bands? This question is valid because some ministers who wear robes may wear full robes as described above; some wear cassock and cincture; while yet others wear only a gown. And there are other variations. Perhaps we need to acknowledge the variety of practice and affirm it as what we do with regard to theological diversity in a "broad" church. Further to the issue of the desirability of enforcement is the matter of the possibility of enforcement. Are we to police what ministers wear or do not wear and how can this be done effectively, if at all?

The issue of adiophora (non-essentials) has to be taken seriously. In view of the aforementioned, vestments can only be considered an aid to worship and spirituality. They may make sense in a large gathering but be out of place in an informal setting (White 1971:98) where the emphasis is on intimacy and spontaneity. Perhaps we might agree with the PCSA General Assembly (1988a:31) that "the principle inherent in the adoption of a form of dress (ought to be) synonymous with the authority to expound the scriptures."

A further issue might be to look at the issue from the opposite perspective. Since we are all part of a priestly people, a royal priesthood, the priesthood of all believers, why stop with the minister - let all dress up for example as in choirs and in the use of the prayer shawl by orthodox Jews? This was the practice of the Early Church where all neophytes (candidates) wore a white garment as a symbol of innocence. (Yarnold 1978:104).

The abandonment of clerical wear might be considered unwise, because functionally, it can create confusion; theologically and historically, it 
might be considered contemptuous of tradition and is therefore pastorally unacceptable. Aesthetically, contemporary dress is considered by many as unattractive as a model. Ordinary dress may reflect "a rather negative form of egalitarianism, and reduction to the lowest common denominator" (White 1971:120). If clerical dress is retained, it should be related, though not necessarily copied, to the tradition of the past. We have such a rich heritage that there is no need for novelty (Grisbrooke 1978:492). Grisbrooke (1978:488) makes interesting points with regard to dispensing with vestments for it:

is not only psychologically unhealthy, but also in practice all but impossible: if, for example, the celebrant of the Eucharist today decided to wear "ordinary clothes", they immediately cease psychologically, to be ordinary clothes, and become another form of symbolical ecclesiastical garb, their very ordinariness making an extraordinary theological or sociological point.

\section{WHAT IS THE ULTIMATE REQUIREMENT?}

Decency and order (1 Cor 14:40) has been a norm in the Church since its earliest days and has remained so in the Reforming tradition. It is not helpful to legislate in a matter that is not critical to the expression of the faith. It is also unhelpful to cause division, particularly since ministers and elders have sworn to uphold and promote the peace and unity of the Church (UPCSA 1984:125.02E; 205.03E cf PCSA 1988a:32). Permissive (what may be worn) rather than prescriptive (what must be worn) (Weatherhead 1997:58) legislation is a more appropriate norm. It is possible to proceed by avoiding a legalistic approach. The UPCSA Presbytery of Tshwane of the UPCSA (2003:3 cf PCSA 1989a:206, 3) dealt with a problem of dress by agreeing that:

at the following Presbytery services, and on other occasions as the Presbytery may determine from time to time, Presbytery requires ministers and commissioners who participate in Presbytery services to dress formally:

The licensing of Probationers The ordination of Ministers The induction or appointment of Ministers The consecration of Church buildings.

This leaves the definition of what constitutes formal dress to the discretion of each presbyter whether or not $\mathrm{s} / \mathrm{h}$ e wears robes or not. This may appear to be 
a little loose but it does allow for variety within the Reforming tradition which is a historical mark of its practice; it also allows for innovation which is also central to that tradition. But perhaps what is most important of all is that it works in the particular context!

A further matter relates to what is appropriate in each context and this might be determined by a number of factors, for example the minister's approach, the congregation's views, denominational traditions and requirements, local tradition, architecture, nature and dignity of worship celebrated and theology of worship. And here the exercise of liberty of opinion in matters that do not enter into the substance of the faith has to be considered.

From a particularly Reformed perspective we can do no better than agree with Myers (in Doberstein 1986:232) that it is "abiding humility and penitence which are the only appropriate vestments of a man who ventures to speak to others in God's name." Ultimately, it is the clothing of godliness and the manifestation of the gifts (1 Cor 12) and fruits (GI 5:2) of the Spirit that enhances and promotes the glory of God which is our ultimate worship (Larger Catechism 1969:51). In this respect, Groeneveld (2005:2) has outlined several principles which are worthy of consideration:

1. The robes can lend dignity and honour to the act of worshipping God.

2. Clerical vestments should be worn as a signpost pointing to God's holiness and grandeur and not just because tradition dictates it.

3. The New Testament perspective is important. The Old Testament was waiting for the Great High Priest who would sacrifice for once for all. In the New Testament we meet the One who has made the sacrifice required. Our best "spiritual uniform" is to look like Him.

\section{CONCLUSION}

The present situation with regard to dress for worship in one particular branch of the Reforming tradition, southern African Presbyterianism, is sufficiently fluid and inclusive to allow a variety of approaches and viewpoints to be considered inclusive. Any attempt to define narrowly what should/should not or may/may not be worn is likely to be divisive and to disturb the order, peace and unity of the Church. Sprott (1882:244) makes an apposite comment: "Since 1688 the General Assembly [of the Church of Scotland] has issued no regulations on the subject of ecclesiastical costume, and nowadays it would probably be thought beneath the dignity of that venerable body to occupy its 
time with such matters." An awareness of scripture, theology of worship, symbolism, history, tradition and current practice can lead to sensitivity on this non-essential aspect of the life and witness of the Church.

\title{
10. A FINAL WORD
}

\begin{abstract}
A very pretty public stir Is making in the Church, About the clergy fashion: And many bitter words and rude Are interchanged about the feud, And much unchristian passion For me, I neither know nor care Whether a minister ought to wear A black dress, or another, Plagued with a trouble of my own A wife who preaches in her gown, And lectures in her night one.
\end{abstract}

(adapted slightly from Wippell 1989:30)

\section{Works consulted}

Behrendt, R 2001. Theology of dress. The American Benedictine Review 52, 4 437460.

Bradshaw, P F (ed) 2002. The New SCM Dictionary of Liturgy and Worship. London: SCM.

Burnet, G B 1960. The Holy Communion in the Reformed Church of Scotland, 15601960. Edinburgh: Oliver \& Boyd.

Cannon, H B 1992. Sacred clothing: An inside-outside perspective. Dialogue: $A$ Journal of Mormon Thought 25, 138-148.

Carpenter, H J 1957. Minister, Ministry, in Richardson 1957:146-152.

Cope, G 1986. Vestments in Davies J G (ed), 1986:521-540.

Crichton, J D 1978. A theology of worship in Jones, Wainwright \& Yarnold 1978:1-29.

Davies, H 1963. The English Free Churches. London: OUP.

Davies, J G (ed) 1986. A New Dictionary of liturgy and worship. London: SCM.

Doberstein, J W 1986. Minister's prayer book: An order of prayers and readings. Philadelphia, PA: Fortress.

Gossman, K 2004. Vestments, in Salamone 2004:88-93.

Grisbrooke, W J 1978. Vestments in Jones, Wainwright \& Yarnold 1978:488-492.

Groeneveld, T 2005. Priestly garments. Pretoria: Emmanuel Presbyterian Church.

Hamilton, J A 1946. The stole and scarf. The church Service Society Annual 16:2737.

Holeton, D R 2002. Vestments, in Bradshaw 2002:464-471.

James, R 1936. The dress of the liturgy II, tunics. Orate Fratres 10(4), 163-173.

James, R 1936. The dress of the liturgy III, cloaks. Orate Fratres 10(7), 309-319. 
Jones, C, Wainwright, G \& Yarnold, E (eds), 1978. The study of liturgy. London: SPCK.

Lambert, R C 2003. Church clothes. First things: A Monthly Journal of Religion and Public Life 134(13).

Larger Catechism [1648] 1969. Edinburgh: Blackwood.

Lindberg, C 1996. The European Reformations. Oxford: Blackwell.

Macleod, D 1990. Presbyterian worship: Its meaning and method. Atlanta, GA: John Knox.

M'Crie, C G 1892. The public worship of Presbyterian Scotland. Edinburgh: Blackwood.

McEwen, J S 1957. Worship, in Richardson 1957:287-289.

McMillan, W 1931. The worship of the reformed church 1550-1638. London: James Clarke.

McMillan, W 1949. Scottish ecclesiastical dress. The Church Service Society Annual 19, 25-32.

McMillan, W 1949a. Scottish ecclesiastical dress: The cassock. The Church Service Society Annual 20, 32-43.

McNeill, J T 1954. The history and character of Calvinism. New York: OUP.

Marty, M E 201. Sartorial inelegance. Christian Century 118(7), 31.

Maxwell, W D 1936. An outline of Christian worship: Its development and forms. London: OUP.

Maxwell, W D 1948. Concerning worship. London: OUP.

Maxwell, W D 1955. A history of worship in the Church of Scotland. London: OUP.

Maxwell, W D [1931] 1965. The liturgical portions of the Genevan Service Book. Westminster: Faith Press.

Mayo, J 1984. A history of ecclesiastical dress. New York: Holmes \& Meier.

Myers, 1986. "St Paul", in Doberstein 1986:332.

North, C R 1957. Sacrifice, in Richardson 1957:210-211.

Oden T C 1983. Pastoral theology: Essentials of ministry. San Francisco, CA: Harper \& Row.

Presbyterian Church of Southern Africa (PCSA) 1988. Papers for General Assembly. Johannesburg: PCSA.

PCSA 1984. Service book and ordinal. Johannesburg: UPCSA.

PCSA 1988. Papers for General Assembly. Johannesburg: PCSA.

PCSA 1988a. Proceedings and Decisions of General Assembly. Johannesburg: PCSA.

PCSA 1989. Papers for General Assembly. Johannesburg: PCSA.

PCSA 1989a. Proceedings and Decisions of General Assembly. Johannesburg: PCSA.

Presbytery of Tshwane 2003. Minutes of Meeting, 17 May. Pretoria: UPCSA

Richardson, A (ed) 1957. A theological wordbook of the Bible. London: SCM.

Richardson, C C 1953. The library of Christian classics: Early Christian fathers, vol 1. Philadelphia, PA: Westminster.

Roets, P J \& Dreyer, T F J 2001. Die funksie van die toga as liturgiese simbool in die Protestantse tradisie: 'n Kwantitatief-empiriese ondersoek. HTS 57, 13441360.

Ross, J M 1972. Four centuries of Scottish worship. Edinburgh: St Andrew.

Salamone, F A (ed) 2004. Encyclopaedia of religious rites, rituals and restivals. New York: Routledge. 
Senn, F C 1997. Christian liturgy: Catholic and evangelical. Minneapolis, MN: Fortress.

Sly, R W 1999. The living liturgy. http://www.mindspring.com/brandy/articles/living.htm.

Sprott, G W 1882. The worship and offices of the Church of Scotland. Edinburgh: Blackwood.

Steinmetz, D C 1971. Reformers in the wings. Philadelphia, PA: Fortress.

Thurian, M \& Wainwright, G (eds) 1983. Baptism and Eucharist: Ecumenical convergence in celebration. Geneva: WCC.

Tripp, D H 1978. Protestantism and the Eucharist in Jones C, Wainwright G \& Yarnold, E (eds), 1978:248-262.

Tripp D H 1978. Worship and the pastoral office in Jones, C, Wainwright, G \& Yarnold, E (eds) 1978:510-532.

UPCSA 2003. Papers for General Assembly. Johannesburg: UPCSA.

Wainwright, G 1978. The periods of liturgical history in Jones, C, Wainwright, G \& Yarnold, E (eds) 1978:33-38.

Weatherhead, J L (ed) 1997. The constitution and laws of the Church of Scotland. Edinburgh: Board of Practice and Procedure, CofS.

Wippell J 1989. Wippell's: 1789-1989. Wippell's: Exeter.

White J F 1971. New forms of worship. Nashville, TN: Abingdon.

White J F 1980. Introduction to Christian worship. Nashville, TN: Abingdon.

White J F 1989. Protestant worship: Traditions in transition. Louisville, KY: Westminster.

Yarnold E 1978. The fourth and fifth centuries in Jones, C, Wainwright, G \& Yarnold, E (eds), 1978:95-110. 